\title{
UV Spectrophotometric Assay Method for the Determination of Fluconazole Capsules
}

\author{
Safila Naveed, Maheen Nafees \\ Faculty of Pharmacy of Pharmacy, Jinnah University for Women, Karachi, Pakistan \\ Email: safila117@yahoo.com
}

Received 28 March 2015; accepted 11 April 2015; published 15 April 2015

Copyright (C) 2015 by authors and OALib.

This work is licensed under the Creative Commons Attribution International License (CC BY). http://creativecommons.org/licenses/by/4.0/

(c) (i) Open Access

\section{Abstract}

A very simple, accurate, rapid and economical UV spectrophotometric method was developed for the estimation of fluconazole. The UV method permits a simple, rapid and economical quantitation of fluconazole in capsule dosage form only. The maximum absorbance of fluconazole was found to be $210 \mathrm{~nm}$. Fluconazole, which is available in Karachi in different brands within the pharmacies, was collected and used for this assay method. The results showed that the assay results of the two brands were in range. This study would turn out to be very beneficial and with this simple and accurate method, one can easily determine fluconazole.

\section{Keywords}

\section{Fluconazole, Spectrophotometer, Assay \\ Subject Areas: Pharmacology, Public Health}

\section{Introduction}

Fluconazole (FLK) is chemically known as [2-(2,4,-difluorophenyl)-1,3-bis(1H1,2,4,-triazol-1-yl)propan-2-ol] [1]. FLK is an official drug in United States Pharmacopeia [2], European Pharmacopoeia [3] and British Pharmacopoeia [4]. It is a synthetic bis-triazole derivative broad-spectrum antifungal drug and has been shown to be effective against a wide range of superficial fungal infections and systemic fungal infections, following both oral and intravenous administration [5]. It is recommended for the treatment of oropharyngeal, esophageal, or vulvovaginal candidiasis and prophylaxis treatment of disseminated and deep organ candidiasis [6]. Yeast infections have been prevented in patients who are likely to become infected, because these patients are being treated with chemotherapy or radiation therapy by this drug before a bone marrow transplant [7] [8]. FLK is a highly selective inhibitor of fungal cytochrome P450 sterol C-14 (x-demethylation). Hence, this drug performs its action by inhibiting the synthesis of ergosterol, therefore blocking the cell membrane formation [9] (Figure 1). 


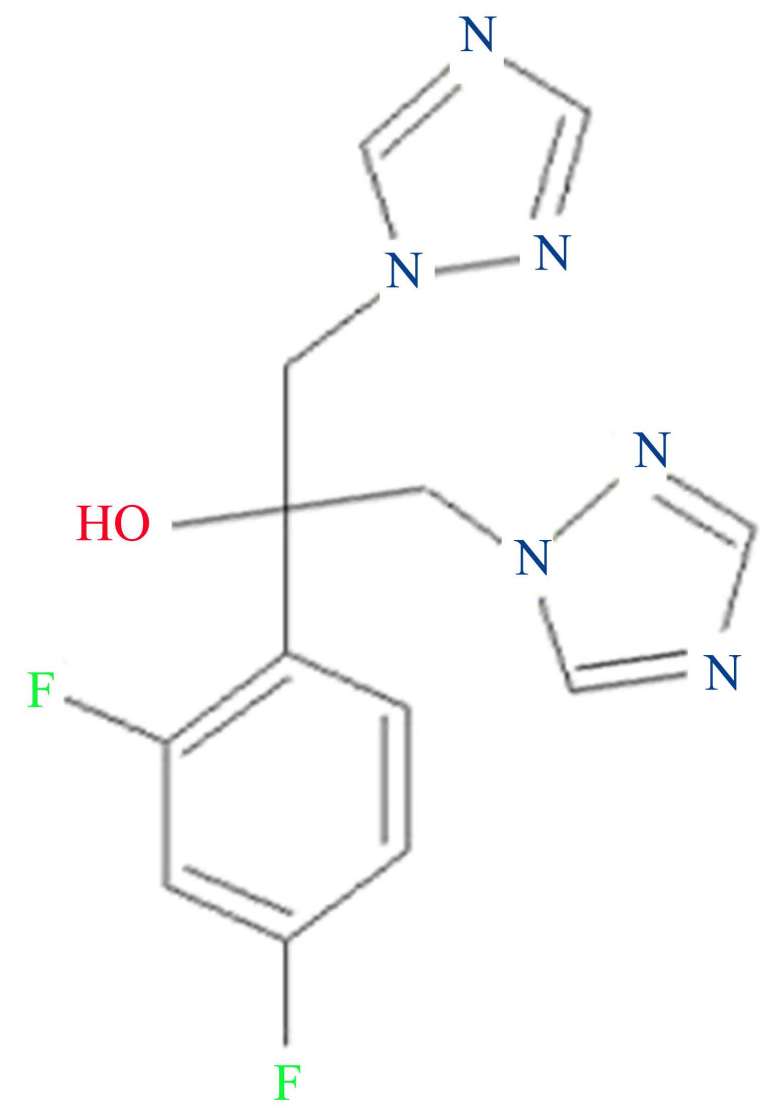

Figure 1. Structure of fluconazole [10].

The literature survey revealed the availability of many techniques for the determination of FLK by assay methods in pharmaceuticals. Quantification of FLK both alone as well as in combined formulations has been achieved by high-performance liquid chromatography (HPLC) [11]. UV-Visible-Spectrophotometry [12] and High Performance Thin Layer Chromatography (HPTLC) [13] are also reported for the quantification of FLK in formulations. A number of ultra performance liquid chromatographic methods have also been reported for the assay of FLK in mixed pharmaceuticals [14]. In recent years, there has been an increasing tendency observed towards development of stability-indicating assays [15] [16].

In 2014, Singh et al. [17] developed and validated new HPLC-methods for the determination of FLK. Also Sadasivudu et al. [18] in 2009 and Zhang et al. [19] in 2008 developed the HPLC methods for FLK estimation. In 2012, Alizadeh et al. [20] developed a rapid and simple spectrophotometric method to determine the concentration of FLK, Ketoconazole and Clotrimazole. Also Singh et al. [21] in 2011 developed and validated a sensitive and accurate UV-spectrophotometric method for the estimation of FLK in raw material and in tablets.

Spectrophotometric technique is based on measuring the absorption of a monochromatic light in the near ultraviolet region (200-380 nm). The aim of the study is to develop a simple, rapid, precise and economical UV spectrophotometric method for the determination of FLK in capsule dosage form.

\section{Materials and Methods [22]-[25]}

\subsection{Instruments}

For the measurement of Absorbance, Spectrophotometer (Schimadzu UV-1800 Spectrophotometer) was used and for the weighing of this method Digital Balance was used. Sonicator was also used in this assay method. For weighing, analytical balance was also used for this and an ultrasonic bath (Ultrasonic LC60H Elma Japan) was used as well. 


\subsection{Reagents and Chemicals}

All chemicals were used as Analytical Grade and FLK's brands sample were searched from different pharmacies for the usage. De-ionized water was used throughout the investigation.

\subsection{Preparation of Fluconazole Solution of Different Brands}

Separately weigh each capsule of the two brands of FLK. Take out the powdered material by removing cap of the capsules. Accurately weighed powder equivalent to $20 \mathrm{mg}$ of FLK in a tare beaker for each brand i.e. FLK -01 and FLK -02 and was sonicated for $20 \mathrm{~min}$ in an ultrasonic bath for the complete dissolution of the FLK, the content was then diluted to the mark with the de-ionized water, mixed well and filtered using a $0.22 \mu \mathrm{m}$ nylon membrane filter paper. Then these solutions were transferred into four different $100 \mathrm{ml}$ volumetric flasks. Finally make-up the volume with de-ionized water to $100 \mathrm{ml}$ for each sample. This stock solution is used to make further dilutions of individual brands in concentration of about 50, 25, 12.5 and 6.25. All these solutions are then determined for their absorbance by using UV-Visible spectrophotometer, the absorbance of solutions of each brand of FLK was determined at wavelength max of $210 \mathrm{~nm}$ using blank as de-ionized water. The absorbance of the two brands are given in Table 1 and Table 2.

\section{Results and Discussions}

The UV method permits a simple, rapid and economical quantitation of fluconazole in capsule dosage form only. The $\lambda \max$ was found to be $210 \mathrm{~nm}$. A very simple and economical method was developed to find the estimation of FLK which was carried out by using spectrophotometer on the two different brands of fluconazole available in Karachi pharmacies. Five different dilutions of the two brands were prepared (100 ppm, 50 ppm, 25 ppm, $12.5 \mathrm{ppm}$ and $6.25 \mathrm{ppm}$ ) and their absorbance is shown in Table 1 and Table 2. The results of \% assay were found in range; the results of their percent assay are shown in Table 3, and regression equation and regression line are obtained. For the detection of linearity, absorbance of these prepared different solutions of $100 \mathrm{ppm}, 50$ ppm, 25 ppm, 12.5 ppm and 6.25 ppm was taken. For linearity we use different concentrations from 100 ppm to $6.25 \mathrm{ppm}$ and graph shows linear relationship between absorbance and concentration (Figure 2 and Figure 3).

Table 1. Absorbance of flk-01.

\begin{tabular}{|cc|}
\hline Concentration ppm & Absorbance at $\mathbf{2 1 0} \mathbf{~ n m}$ \\
\hline 100 & 2.356 \\
50 & 1.25 \\
25 & 0.625 \\
12.5 & 0.32 \\
6.25 & 0.15 \\
\hline
\end{tabular}

Table 2. Absorbance of flk-02.

\begin{tabular}{cc}
\hline Concentration ppm & Absorbance at 210 $\mathbf{~ m}$ \\
\hline 100 & 2.366 \\
50 & 1.26 \\
25 & 0.67 \\
12.5 & 0.37 \\
6.25 & 0.17 \\
\hline
\end{tabular}

Table 3. Results of \% assay of different brands.

\begin{tabular}{ccc}
\hline Brand name & Absorbance at $\mathbf{2 1 0} \mathbf{~ n m}$ & \% Assay \\
\hline FLK-01 & 2.356 & 100.68 \\
FLK-02 & 2.366 & 101.10 \\
\hline
\end{tabular}




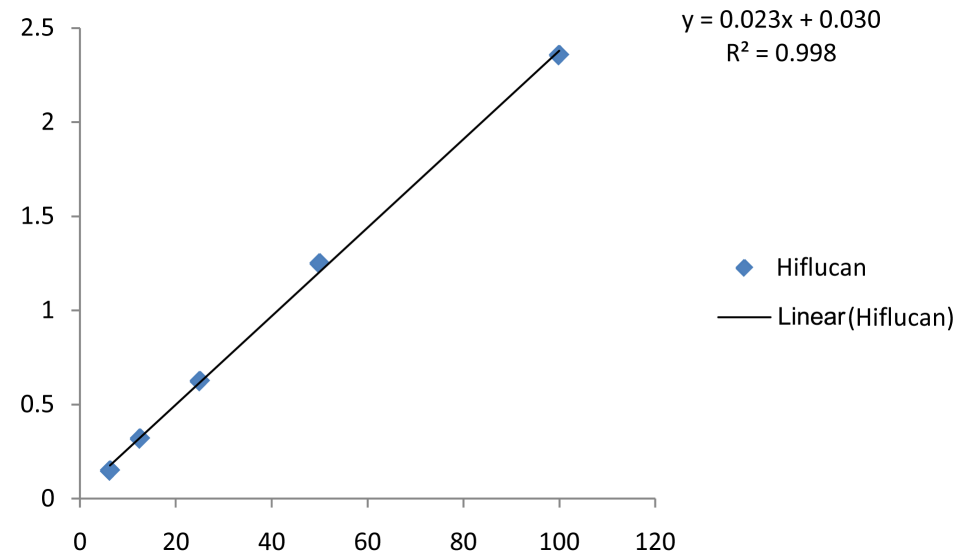

Figure 2. Linearity and range of flk-01 (hiflucan).

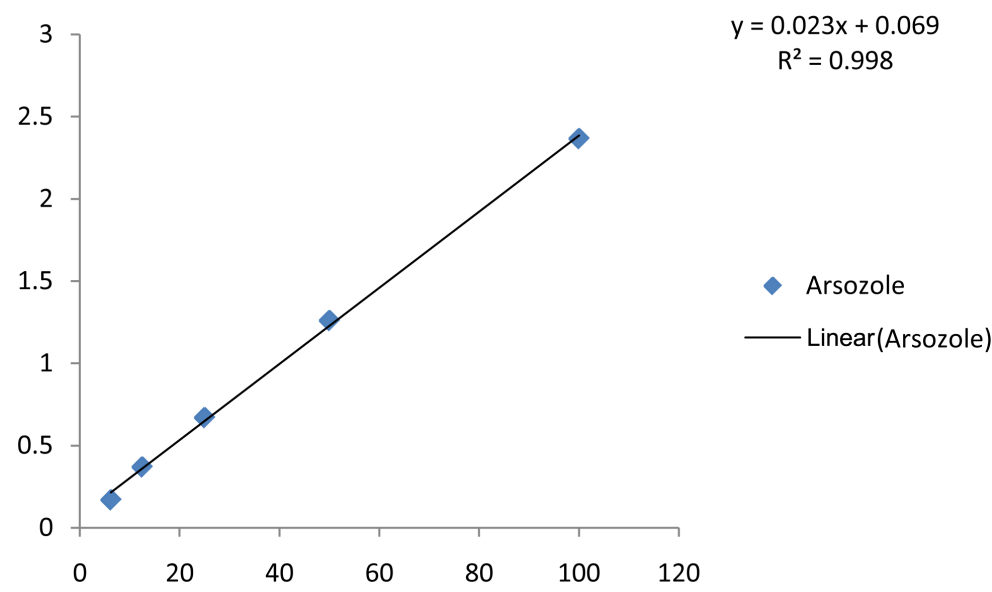

Figure 3. Linearity and range of flk-02 (arsozole).

Squared correlation coefficient of each brand is shown which should not be less than 0.99. Squared correlation coefficient values of all the brands of FLK are well within the limit. In all results we find acceptable degree of linearity. All three brands of FLK showed linear relation with their dilution (Figure 2 and Figure 3).

\section{References}

[1] Merck \& Co., Inc. (2006) The Merck Index. 14th Edition, Merck \& Co., Inc., Whitehouse Station, Monograph No. 0004122.

[2] USP Convention (2012) United States Pharmacopeia, USP35, National formulary-32. USP Convention, Rockville, Fluconazole, 3204-3205.

[3] Council of Europe (2012) European Pharmacopoeia, EDQM. Edition 7.6, Council of Europe, Strasbourg, $4936-4937$.

[4] Stationery Office (2009) Pharmacopoeia. Her Majesty’s, Stationery Office, London, 1\&2 Monograph No. 2287.

[5] Martindale (1996) The Extra Pharmacopoeia. Reynolds, J.E.F., Ed., 31st Edition, Royal Pharmaceutical Society, London, 404-406.

[6] Saurabh, P., Preeti, P., Shaifali, D., Udisha, C. and Awani, K.R. (2012) Facile Derivative UV Spectroscopy Method: Simultaneous Estimation of Tinidazole and Fluconazole in Combined Tablet Dosage Form. Thai Journal of Pharmaceutical Sciences, 36, 55-62.

[7] Porta, V., Chang, K.H. and Storpirtis, S. (2005) Evaluation of the Bioequivalence of Capsules Containing $150 \mathrm{mg}$ of Fluconazole. International Journal of Pharmaceutics, 288, 81-86. http://dx.doi.org/10.1016/j.ijpharm.2004.09.013

[8] Joseph, T.D., Robert, L.T., Gary, C.Y., Gary, R.M., Barbara, G.W. and Michael, P. (2005) Pharmacotherapy: A Pathophysiologic Approach. 6th Edition, McGraw Hill, London. 
[9] Lacy, C.F., Armstrong, L.L., Goldman, M.P. and Lance, L.L. (2006) Drug Information Handbook. 15th Edition, LEXICOMP, Ohio.

[10] Kai, B.L., Gabriel, O.K.L., Yvonne, T.F.T. and Khiang, K.O.K. (2012) Development and Application of Simple HPLCUV Method for Fluconazole Quantification in Human Plasma. International Journal of Pharmacy and Pharmaceutical Sciences, 4, 107-111.

[11] Abdel-Aleem, A.A., Lotfy, H.M. and Monir, H.H. (2012) Stability-Indicating High Performance Liquid Chromatographic Determination of Fluconazole in the Presence of Its Oxidative Degradation-Kinetic and Stress Study. International Research Journal of Pharmaceuticals, 2, 6-12.

[12] Gondalia, R.P., Patel, D.P. and Savaliya, P.J. (2010) Development and Validation of UV Spectrophotometric Method for Estimation of Fluconazole in Soft Gelatin Capsule. International Journal of Pharmacy and Technology, 2, 938-944.

[13] Shewiyo, D.H., Kaale, E., Risha, P.G., Dejaegher, B., Smeyers-Verbeke, J. and Vander, H.Y. (2012) HPTLC Methods to Assay Active Ingredients in Pharmaceutical Formulations: A Review of the Method Development and Validation Steps. Journal of Pharmaceutical and Biomedical Analysis, 66, 11-23. http://dx.doi.org/10.1016/j.jpba.2012.03.034

[14] Yanamandra, R., Chaudhary, A., Bandaru, S.R., Sastry, C.S.P., Patro, B., Murthy, Y.L.N. and Ramaiah, P.A. (2011) Development of a RP-UPLC Method for the Simultaneous Analysis of Secnidazole, Fluconazole, and Azithromycin: Application in Pharmaceuticals and Human Serum. International Journal of PharmTech Research, 3, 1198-1207.

[15] Vinay, K.B., Revanasiddappa, H.D., Xavier, C.M., Ramesh, P.J. and Raghu, M.S. (2012) A Stability Indicating UPLC Method for the Determination of Tramadol Hydrochloride: Application to Pharmaceutical Analysis. Chromatography Research International, 2012, Article ID: 870951.

[16] Lotfy, H.M., Abdel-Aleem, A.A. and Monir, H.H. (2013) Stability-Indicating High Performance Liquid Chromatographic Determination of Fluconazole in the Presence of Its Oxidative Degradation Product-Kinetic and Stress Study. Journal of Liquid Chromatography \& Related Technologies, 36, 1013-1029.

[17] Singh, A., Sharma, P.K. and Majumdar, D.K. (2014) Development and Validation of New HPLC-Methods for Estimation of Fluconazole in Different Simulated Biological Fluids: A Comparative Study. Journal of Liquid Chromatography \& Related Technologies, 37, 594-607. http://dx.doi.org/10.1080/10826076.2012.758131

[18] Sadasivudu, P., Shastri, N. and Sadanandam, M. (2009) Development and Validation of RP-HPLC and UV Methods of Analysis for Fluconazole in Pharmaceutical Solid Dosage Forms. International Journal of ChemTech Research, 1, 1131-1136.

[19] Zhang, S.M., Mada, S.R., Torch, M., Goyal, R.K. and Venkataramanan, R. (2008) Development and Validation of a High-Performance Liquid Chromatographic Assay for the Determination of Fluconazole in Human Whole Blood Using Solid Phase Extraction. Therapeutic Drug Monitoring, 30, 314-319. http://dx.doi.org/10.1097/FTD.0b013e31816c7404

[20] Alizadeh, N. and Rezakhani, Z. (2012) Extractive Spectrophotometric Determination of Ketoconazole, Clotrimazole and Fluconazole by Ion-Pair Complex Formation with Bromothymol Blue and Picric Acid. Journal of the Chilean Chemical Society, 57, 1104-1108. http://dx.doi.org/10.4067/S0717-97072012000200010

[21] Singh, A., Sharma, P.K. and Majumdar, D.K. (2011) Development and Validation of Different UV-Spectrophotometric Methods for the Estimation of Fluconazole in Bulk and in Solid Dosage Form. Indian Journal of Chemical Technology, 18, 357-362.

[22] Naveed, S. and Qamar, F. (2014) Simple UV Spectrophotometric Assay of Metronidazole. Open Access Library Journal, 1, 1-4. http://dx.doi.org/10.4236/oalib.1100615

[23] Naveed, S., Ashraf, Z. and Mukhtar, T. (2014) Assay of Different Brands of Cefadroxil by Using Spectrophotometric Method. Mintage Journal of Medical and Pharmaceutical Sciences, 3, 12-14.

[24] Naveed, S., Shah, S.N., Qamar, F., Waheed, N. and Nazeer, S. (2014) Simple UV Spectrophotometric Assay of New Formulation Gentamycin. Journal of Applied Pharmacology, 6, 407-410.

[25] Naveed, S. and Zafar, F. (2014) UV Spectrophotometric Assay of Famotidine Formulations. American Journal of Pharmacy and Pharmacology, 1, 28-31. http://www.aascit.org/journal/archive?journalId=922

\section{Abbreviations}

FLK: Fluconazole

FLK-01: Fluconazole Brand 01

FLK-02: Fluconazole Brand 02 